\title{
Terapi Antiretroviral Lini Kedua pada HIV Anak di RS. Cipto Mangunkusumo
}

\author{
Dina Muktiarti, Arwin AP Akib, Zakiudin Munasir, Nia Kurniati \\ Departemen Ilmu Kesehatan Anak, Fakultas Kedokteran Universitas Indonesia/RS. Cipto Mangunkusumo, \\ Jakarta
}

Latar belakang. Akses terhadap terapi antiretroviral (ARV) semakin mudah saat ini dan membuat angka harapan hidup anak terinfeksi HIV semakin panjang. Dalam penanganan jangka panjang anak terinfeksi HIV, salah satu masalah baru yang timbul adalah gagal terapi dan resistensi obat.

Tujuan. Menilai karakteristik pasien anak terinfeksi di RS. Cipto Mangunkusumo yang menggunakan terapi ARV lini kedua dan indikasi penggantian ke terapi ARV lini kedua.

Metode. Penelitian kohort pasien anak terinfeksi HIV di RS Cipto Mangunkusumo sejak tahun 2002. Kriteria inklusi adalah pasien anak terinfeksi HIV yang berobat di RS Cipto Mangunkusumo sejak tahun 2002 sampai April 2012 dan menggunakan salah satu obat antiretroviral lini kedua. Data yang diambil adalah data demografis, kada CD4, jumlah virus, stadium klinis, dan kombinasi terapi ARV.

Hasil. Empatratus empat pasien anak terinfeksi HIV dan 44 (10,9\%) menggunakan terapi antiretroviral lini kedua. Sebagian besar $(59,1 \%)$ gagal terapi adalah kombinasi antara kegagalan virologi, imunologis, dan klinis. Median usia saat memulai terapi ARV lini kedua 69 (26-177) bulan. Median lama subyek menggunakan terapi ARV lini pertama 9 (13-176) bulan. Seluruh subyek penelitian menggunakan lopinavir/ ritonavir sebagai salah satu obat ARV lini kedua dengan kombinasi terbanyak adalah didanosin, lamivudin, dan lopinavir/ritonavir (40,9\%). Efek samping didapatkan pada 2 pasien akibat abacavir. Sebagian besar subyek (19/25) yang diperiksa jumlah virus pada 6-12 sesudah menggunakan ARV lini kedua mempunyai hasil tidak terdeteksi.

Kesimpulan. Jumlah pasien yang menggunakan terapi ARV lini kedua tidak terlalu banyak karena deteksi kegagalan terapi masih lebih banyak berdasarkan kegagalan klinis dan imunologis.

Sari Pediatri 2012;14(2):130-6.

Kata kunci: anak terinfeksi HIV, terapi antiretroviral lini kedua, gagal terapi

Alamat korespondensi:

Dr. Dina Muktiarti, Sp.A. Departemen Ilmu Kesehatan Anak FKUIRSCM, Divisi Alergi-Imunologi. Jl. Salemba 6, Jakarta 10430. Telp. (021) 316 1144. Fax. (021) 3913982.
A

ngka kejadian anak terinfeksi human immunodeficiency virus (HIV) semakin meningkat di Indonesia. Data Kementrian Kesehatan Republik Indonesia pada triwulan pertama tahun 2012 menunjukkan bahwa sejak tahun 
1987 sampai awal 2012 terdapat 82.870 kasus infeksi HIV di Indonesia. Kasus anak terinfeksi HIV sejak tahun 2010 sampai dengan Maret 2012 1,4\% (696 orang) dari 48.456 kasus. Jumlah tersebut meningkat dibandingkan laporan sebelumnya yang mencatat 366 kasus anak di bawah usia 15 tahun menderita acquired immunodeficiency syndrome (AIDS) sampai akhir tahun 2008. ${ }^{1,2}$

Terdapat akses untuk obat ARV di seluruh dunia termasuk Indonesia, sehingga prognosis anak terinfeksi HIV akan menjadi lebih baik. Hal tersebut terlihat dari angka kematian pasien terinfeksi HIV yang turun., Salah satu konsekuensi angka harapan hidup yang meningkat dari anak terinfeksi HIV adalah timbul masalah baru antara lain kegagalan terapi dan masalah resistensi obat. Resistensi obat ARV merupakan konsekuensi supresi yang tidak sempurna dari replikasi HIV oleh obat ARV.

Masalah resistensi obat dan kegagalan terapi pada anak terinfeksi HIV belum banyak dipublikasi terutama di Indonesia. Obat-obat antiretroviral (ARV) di Indonesia tersedia dimulai dengan obat ARV lini pertama dan hanya dua macam obat yaitu zidovudin dan lamivudin. Formulasi untuk anak baru tersedia sejak tahun 2009 dan sebelumnya anak yang memerlukan obat ARV akan memakai tablet dewasa yang dibelah atau dibuat puyer.

Kegagalan terapi dapat diketahui dari kegagalan virologi, kegagalan imunologi, atau kegagalan klinis. Kriteria kegagalan terapi yang diterapkan di Indonesia masih mengacu kepada kriteria yang dibuat oleh WHO. ${ }^{6}$ Kriteria kegagalan terapi WHO lebih banyak mengandalkan kriteria kegagalan klinis dan imunologis. ${ }^{7}$ Berbeda dengan kriteria kegagalan yang direkomendasikan oleh negara maju seperti rekomendasi The National Institutes of Health yang memasukkan kriteria kegagalan virologi sebagai dasar untuk pindah ke terapi ARV lini kedua. ${ }^{8}$ Namun sebenarnya angka sensitivitas dan spesifisitas kriteria imunologis dan klinis sangat rendah untuk memprediksi kegagalan virologi sebagai penanda awal kegagalan terapi. ${ }^{9-10}$ Namun, memasukkan kriteria kegagalan virologi juga tidak mudah dilakukan karena pasien anak terinfeksi HIV di negara-negara berkembang di Afrika dan Asia termasuk di Indonesia tidak selalu mempunyai akses yang mudah untuk dapat memeriksakan PCR RNA HIV, atau jumlah virus untuk mengetahui kegagalan virologi sebagai tanda awal kegagalan terapi. ${ }^{11}$

Masalah resistensi pada anak merupakan salah satu masalah yang belum dapat diketahui dengan pasti di Indonesia, karena pemeriksaan resistensi di Indonesia saat ini masih dalam tahap penelitian yang sedang berlangsung. Sehingga apabila seorang anak terinfeksi HIV mengalami kegagalan terapi, pemilihan terapi ARV selanjutnya dilakukan berdasarkan panduan baku dan tidak dapat disesuaikan dengan resistensi obat ARV yang telah dialami. Laporan pasien anak terinfeksi HIV di Indonesia yang menggunakan terapi ARV lini kedua belum pernah dipublikasi. Rumah Sakit Cipto Mangunkusumo merupakan salah satu rumah sakit yang melayani kasus pasien terinfeksi HIV dengan kasus yang cukup besar baik kasus dewasa maupun anak. Penelitian kami merupakan penelitian awal yang bertujuan untuk mengetahui karakteristik pasien anak terinfeksi di RS. Cipto Mangunkusumo yang menggunakan terapi ARV lini kedua.

\section{Metode}

Penelitian kohort pasien anak terinfeksi HIV di RS Cipto Mangunkusumo sejak tahun 2002. Kriteria inklusi adalah pasien anak terinfeksi HIV yang berobat di RS Cipto Mangunkusumo sejak tahun 2002 sampai April 2012 dan menggunakan salah satu obat antiretroviral lini kedua. Data yang dikumpulkan yaitu usia, jenis kelamin, gejala klinis, stadium klinis awal dan saat pindah ke obat antiretroviral lini kedua, CD4 dan jumlah virus (PCR RNA HIV) saat awal diagnosis, saat pindah ke terapi ARV lini kedua, dan 6-12 bulan setelah menggunakan terapi ARV lini kedua. Alasan menggunakan terapi antiretroviral lini kedua, kriteria gagal terapi pada subyek, lama menggunakan terapi antiretroviral lini pertama, kombinasi terapi antiretroviral lini pertama, kombinasi terapi antiretroviral lini kedua, efek samping obat-obat antiretroviral lini kedua, dan keadaan terakhir subyek (hidup, meninggal, atau lost to follow up).

Obat-obatan yang termasuk obat antiretroviral lini kedua adalah abacavir, didanosin, tenofovir, lopinavir/ ritonavir. Alasan menggunakan terapi antiretroviral lini kedua adalah gagal terapi atau terdapat efek samping dengan obat-obatan antiretroviral lini pertama.

Kriteria gagal terapi adalah kegagalan klinis, kegagalan imunologis, dan kegagalan virologi berdasarkan kriteria WHO. Kegagalan klinis apabila terdapat gejala klinis baru yang termasuk dalam kriteria stadium klinis WHO 3 atau 4 pada seorang 
anak terinfeksi HIV yang mempunyai kepatuhan baik dengan terapi antiretroviral. Kegagalan imunologis apabila terdapat penurunan kadar CD4 di bawah nilai normal sesuai usia (kurang dari $200 \mathrm{sel} / \mathrm{mm}^{3}$ atau kurang dari $10 \%$ untuk anak berusia 2-5 tahun atau CD4 kurang dari $100 \mathrm{sel} / \mathrm{mm}^{3}$ untuk anak berusia lebih dari 5 tahun) atau terdapat kegagalan kenaikan CD4 dengan terapi antiretroviral. Sedangkan kegagalan virologi terjadi apabila seorang anak terinfeksi HIV yang patuh dengan terapi antiretroviral masih memiliki jumlah virus lebih dari $5000 \mathrm{kopi} / \mathrm{ml}$ setelah lebih dari 24 minggu dari inisiasi terapi antiretroviral.

\section{Hasil}

Empatratus empat pasien anak terinfeksi HIV dan 44 $(10,9 \%)$ menggunakan terapi antiretroviral lini kedua
(Tabel 1).

Seluruh subyek mempunyai alasan pindah ke terapi antiretroviral lini kedua yang sama yaitu karena kegagalan terapi antiretroviral lini pertama. Tidak ada subyek penelitian yang pindah ke terapi ARV lini kedua karena efek samping obat-obat ARV lini pertama. Dasar penilaian kegagalan terapi tertera pada Tabel 2. Data subyek penelitian saat pindah ke terapi antiretroviral lini kedua tertera pada Tabel 3 .

Pemantauan jumlah virus setelah jangka waktu 6-12 bulan pemakaian ARV pada 25 pasien didapatkan jumlah virus tidak terdeteksi pada 19 pasien, jumlah virus antara $400-5000 \mathrm{kopi} / \mathrm{ml}$ pada 5 pasien, dan 1 pasien masih mempunyai jumlah virus lebih dari $5000 \mathrm{kopi} / \mathrm{ml}$. Efek samping yang terjadi pada subyek penelitian akibat terapi ARV lini kedua 2 pasien mengalami nyeri perut dan muntah setelah mendapatkan abacavir. Pada saat tulisan kami

Tabel 1. Karakteristik subyek saat diagnosis pertama $(\mathrm{n}=44)$

\begin{tabular}{lc}
\hline Variabel & Median (rentang); $\mathrm{n}(\%)$ \\
\hline Usia diagnosis (bulan) & $30(1-93)$ \\
Usia saat memulai terapi ARV lini 1 & $35(1-94)$ \\
Jenis kelamin; n(\%) & \\
$\quad$ Laki-laki & $28(63,6)$ \\
Perempuan & $16(36,4)$ \\
Stadium klinis awal; n (\%) & \\
Stadium 1 & $2(4,5)$ \\
Stadium 2 & $5(11,4)$ \\
Stadium 3 & $18(40,9)$ \\
Stadium 4 & $19(43,2)$ \\
CD4 absolut saat diagnosis (sel/ $\mu \mathrm{L}) ; \mathrm{n}=42$ & $253,5(3-1801)$ \\
CD4 persentase saat diagnosis (\%); n=35 & $7(0-33)$ \\
Jumlah virus/viral load saat awal diagnosis (kopi/ml); n=22 & $583996(32405-6.400 .000)$ \\
Kombinasi terapi antiretroviral lini pertama; $(\%)$ & \\
Zidovudin/lamivudin/nevirapin & $28(63,6)$ \\
Stavudin/lamivudin/nevirapin & $8(18,2)$ \\
Zidovudin/lamivudin/efavirenz & $4(9,1)$ \\
Zidovudin/lamivudin/nelvinafir & $1(2,3)$ \\
Zidovudin/lamivudin & $3(6,8)$ \\
\hline
\end{tabular}

Tabel 2. Dasar kegagalan terapi

\begin{tabular}{ll}
\hline Dasar gagal terapi & Jumlah $(\%)$ \\
\hline Kegagalan klinis, imunologis, dan virologi & $26(59,1)$ \\
Kegagalan klinis dan imunologi & $2(4,6)$ \\
Kegagalan imunologi dan virologi & $9(20,5)$ \\
Kegagalan virologi saja & $7(15,9)$ \\
\hline
\end{tabular}


dibuat sejumlah $38(86,4 \%)$ subyek hidup, $2(4,5 \%)$ meninggal, 3 (6,8\%) dirujuk ke rumah sakit lain, dan $1(2,3 \%)$ lost to follow up. Penyebab kematian adalah limfoma malignum pada 1 pasien dan 1 pasien lain meninggal di rumah setelah putus obat ARV lini kedua.

\section{Pembahasan}

Anak terinfeksi HIV yang menggunakan terapi antiretroviral lini kedua di RS. Cipto Mangunkusumo sejumlah 44 orang $(10,9 \%)$. Jumlah tersebut lebih kecil dibandingkan dengan penelitian di Thailand dan

Tabel 3. Karakteristik subyek pada saat pindah ke terapi antiretroviral lini kedua $(\mathrm{n}=44)$

\begin{tabular}{|c|c|}
\hline Variable & Median (rentang); \% \\
\hline Usia & $69(26-177)$ \\
\hline \multicolumn{2}{|l|}{ Stadium klinis; n (\%) } \\
\hline Stadium 1 & $3(6,8)$ \\
\hline Stadium 2 & $13(29,5)$ \\
\hline Stadium 3 & $21(47,7)$ \\
\hline Stadium 4 & $7(15,9)$ \\
\hline CD4 absolut $($ sel $/ \mu \mathrm{L})$ & $272,5(7-1721)$ \\
\hline CD4 persentase (\%) & $9(0-40)$ \\
\hline Jumlah virus/viral load (kopi/ml), $\mathrm{n}=42$ & $232.000(503-2.900 .000)$ \\
\hline Lama menggunakan terapi antiretroviral lini pertama & $29(13-176)$ \\
\hline \multicolumn{2}{|l|}{ Kombinasi terapi antiretroviral lini kedua } \\
\hline Didanosin/lamivudin/lopinavir/ritonavir & $18(40,9)$ \\
\hline Abacavir/lamivudin/lopinavir/ritonavir & $16(36,4)$ \\
\hline Abacavir/didanosin/lopinavir/ritonavir & $1(2,3)$ \\
\hline Didanosin/zidovudin/lopinavir/ritonavir & $4(9,1)$ \\
\hline Didanosin/tenofovir/lopinavir/ritonavir & $3(6,8)$ \\
\hline Didanosine/abacavir/lopinavir/ritonavir & $1(2,3)$ \\
\hline Emtricitabine/tenofovir/lopinavir/ritonavir & $2(4,5)$ \\
\hline
\end{tabular}

Tabel 4. Perbandingan karakteristik awal subyek penelitian dengan penelitian lain

\begin{tabular}{lccccc}
\hline Karakteristik & Penelitian ini & Thai $^{* 11}$ & Iedea $^{13}$ & Malawi*14 $^{*}$ & Asia/Afrika*15 $^{*}$ \\
\hline - Usia saat memulai terapi & 30 & TAD & 37 & 2,9 & 2,6 \\
- ARV lini pertama (median & $(1-93)$ bulan & & $(13-86)$ bulan & $(0,1-18,7)$ & $\begin{array}{c}(1,7-3,7) \\
\text { tahun }\end{array}$ \\
$\begin{array}{l}\text { (rentang) } \\
\text { - Jenis kelamin (perempuan,\%) }\end{array}$ & 36,4 & 52,3 & 45 & 47 & 47,1 \\
- Stadium klinis WHO 3 atau & 84,1 & 52 & 74 & TAD & 68,2 \\
4 (\%) & & & & \\
- CD4 absolut & $253,5(3-1801)$ & $151(35-477)$ & TAD & TAD & TAD \\
- CD4 \% & $7(0-33)$ & $7(3-15)$ & $10(5-15)$ & TAD & TAD \\
- Kombinasi terbanyak terapi & AZT/3TC/ & Kombinasi & Kombinasi dengan & d4T/3TC/ & d4T/3TC/ \\
ARV lini pertama & NVP (63,6\%) & 2NRTI dengan & d4T /3TC/ 1 & NVP (96,2\%) & NVP $(60,8)$ \\
& & NVP (70\%) & NNRTI $(80 \%)$ & & \\
\hline
\end{tabular}

Keterangan:

*: Seluruh pasien anak terinfeksi HIV baik yang menggunakan terapi ARV lini pertama maupun ARV lini kedua.

TAD: tidak ada data; AZT: zidovudin; d4T: stavudin; 3TC: lamivudin; NVP: nevirapin 
Afrika. Ruel $\mathrm{dkk}^{12}$ menemukan $13 \%$ anak terinfeksi HIV di Uganda akan mengalami kegagalan virologi pada median waktu kurang lebih 2,5 tahun. Davies $\mathrm{dkk}^{13}$ mendapatkan 19,3\% anak terinfeksi HIV di 7 pusat penanganan HIV di Afrika Selatan akan mengalami kegagalan virologi dalam waktu 3 tahun setelah memulai terapi ARV lini pertama. Sementara Bunupuradah $\mathrm{dkk}^{10}$ menemukan angka lebih tinggi 32,7\% anak terinfeksi HIV yang mengalami kegagalan virologi dalam waktu 2 tahun. Berbeda pada penelitian di Malawi dan 48 program penanganan HIV di Asia dan Afrika yang menemukan $1,5 \%$ dan $0,8 \%$ pasien terinfeksi HIV menggunakan terapi ARV lini kedua. ${ }^{14,15}$

Perbedaan angka tersebut disebabkan seluruh pasien dalam ketiga penelitian pertama pemeriksaan PCR RNA HIV atau jumlah virus dan kadar CD4 dilakukan secara rutin, minimal setiap 6 bulan untuk CD4 dan setiap 12 bulan untuk jumlah virus. Sedangkan pada kedua penelitian terakhir, pemantauan kegagalan terapi hanya berdasarkan kriteria klinis dan imunologis berdasarkan kadar CD4. Protokol pemantauan pasien anak terinfeksi HIV di Indonesia meliputi pemeriksaan CD4 minimal setiap 6 bulan, sedangkan pemeriksaan PCR RNA HIV tidak dimasukkan dalam jadwal pemantauan untuk evaluasi respons pengobatan. ${ }^{6}$ Namun kedua pemeriksaan tersebut tidak dapat rutin dilakukan untuk semua pasien karena terdapat kendala biaya, terutama untuk pemeriksaan PCR RNA HIV. Pemeriksaan PCR RNA HIV yang mahal tidak ditanggung oleh jaminan kesehatan dari pemerintah atau asuransi sehingga hanya sedikit pasien dapat mengakses pemeriksaan ini.

Hal ini pula yang menjadi alasan mengapa sebagian besar $(59,1 \%)$ dasar kegagalan terapi pada penelitian kami adalah kegagalan virologi, imunologis, dan klinis. Sebagian kecil subyek pindah ke terapi ARV lini kedua berdasarkan kegagalan virologi. Hal tersebut disebabkan pemeriksaan virologi menunggu saat telah ditemui kegagalan klinis akibat keterbatasan akses pemeriksaan PCR RNA HIV. Anak dengan kegagalan klinis dan/atau imunologis tidak selalu mengalami kegagalan virologi dan tidak perlu pindah ke terapi ARV lini kedua. Namun keterlambatan pindah ke terapi ARV lini kedua dengan replikasi virus yang tinggi dapat mengakibatkan angka resistensi terhadap regimen ARV lini kedua. Pemeriksaan jumlah virus sangat berguna untuk identifikasi kegagalan terapi. Rekomendasi WHO untuk daerah dengan sumber daya terbatas adalah pemeriksaan PCR RNA HIV dilakukan untuk mengkonfirmasi kegagalan klinis dan/atau imunologis. ${ }^{7}$ Kriteria untuk memprediksi gagal virologi secara dini untuk daerah dengan sumber daya terbatas perlu dikembangkan. Colebunders $\mathrm{dkk}^{16}$ mengembangkan alat diagnostik untuk memprediksi kegagalan virologi dengan menggunakan riwayat penyakit, tingkat kepatuhan terhadap pengobatan, dan laboratorium sederhana. Namun, perangkat tersebut perlu diuji lebih lanjut.

Karakteristik awal subyek yang menggunakan terapi ARV lini kedua tidak jauh berbeda dengan penelitian lain di Asia dan Afrika. Terapi ARV lini pertama dimulai saat usia kurang lebih 3 tahun dan sebagian besar dari mereka datang pada kondisi yang cukup berat, ditandai dengan stadium klinis WHO 3 dan 4 pada semua penelitian lebih dari 50\%, serta pada kondisi imunosupresi berat (median CD $4<15 \%$ ). Kombinasi terapi ARV lini pertama sedikit berbeda di antara penelitian, karena mengikuti pedoman nasional masing-masing negara. ${ }^{6,11,13-15}$ Apabila dilihat seluruh penelitian menggunakan panduan WHO untuk memulai terapi ARV lini pertama dengan menggunakan 2 nucleoside reverse transcriptase inhibitorl NRTI (zidovudin atau stavudin dan lamivudin) dan 1 non-nucleoside reverse transcriptase inhibitor/NNRTI yaitu nevirapin. ${ }^{7}$

Median usia saat memulai terapi ARV lini kedua 69 (26-177) bulan. Usia tersebut sedikit lebih tua dibandingkan dengan median usia pada penelitian di Afrika Selatan 51 (26-103) bulan. ${ }^{13}$ Hal tersebut juga terlihat dari median lama menggunakan terapi ARV lini pertama pada penelitian kami jauh lebih lama dibandingkan dengan penelitian gabungan Asia dan Afrika 33 (6-176) bulan dan 27,3 (17,4-30,4) bulan. ${ }^{15}$ Alasan perbedaan tersebut diakibatkan akses yang terbatas untuk pemeriksaan PCR RNA HIV sebagai penanda awal kegagalan terapi. Namun median usia ini jauh lebih muda dibandingkan dengan median usia pada penelitian di kelompok TREAT Asia yaitu 120 (78-145) bulan. ${ }^{10}$

Seluruh subyek penelitian menggunakan lopinavir/ ritonavir sebagai salah satu obat ARV lini kedua dengan kombinasi terbanyak didanosin, lamivudin, dan lopinavir/ritonavir. Kombinasi tersebut tidak sepenuhnya mengikuti rekomendasi nasional yang menganjurkan kombinasi antara didanosin, abacavir, lopinavir/ritonavir untuk pasien yang gagal dengan kombinasi zidovudin atau stavudin dan lamivudin. Karena pada awalnya abacavir belum tersedia di 
Indonesia, sehingga diambil kombinasi didanosin dan lamivudin karena pedoman nasional juga disebutkan bahwa penggunaan lamivudin pada terapi ARV lini kedua dapat dipertimbangkan karena lamivudin dihubungkan dengan ketahanan virus HIV yang berkurang. ${ }^{6}$

Faktor risiko kegagalan terapi atau resistensi obat ARV lini pertama antara lain usia yang lebih muda, mendapatkan kombinasi dengan nevirapin, CD 4\% $<25 \%$ saat awal terapi, dan kepatuhan minum obat yang kurang. ${ }^{9}$ Pada penelitian kami sebagian besar pasien mendapatkan nevirapin sebagai salah satu obat ARV lini pertama. Sedangkan kepatuhan minum obat tidak didokumentasikan dengan baik. Efek samping terdokumentasi pada 2 pasien, dan keduanya mengalami efek samping terhadap abacavir.

Jumlah virus setelah penggunaan terapi ARV lini kedua pada sebagian besar subyek yang dapat diperiksakan menunjukkan hasil tidak terdeteksi. Hal tersebut sesuai dengan penelitian lain yang menemukan bahwa sesudah diberikan obat ARV lini kedua dengan kombinasi lopinavir/ritonavir, proporsi pasien dengan jumlah virus tidak terdeteksi terdapat pada $47 \%$ pasien pada minggu ke-24 dan 69\% pada minggu ke-96. ${ }^{17,18}$ Subyek yang masih teratur kontrol ke RS Cipto Mangunkusumo semuanya masih dalam keadaan hidup. Dua pasien meninggal dengan penyebab limfoma malignum dan setelah putus obat.

Masalah pemberian obat ARV lini kedua adalah penyediaan obat dengan formulasi anak sangat terbatas. Hal tersebut terlihat pada penelitian yang dilakukan oleh TREAT Asia Pediatric HIV Observational Database (TApHOD), The International Epidemiologic Databases to Evaluate AIDS (IeDEA) Southern Africa Paediatric Group. Pada survei yang dilakukan oleh kedua kelompok tersebut didapatkan bahwa sediaan lopinavir/ritonavir sebagai salah satu obat utama pada ARV lini kedua yang berupa sirup atau tablet untuk anak sangat mudah diakses hanya di 10\%-80\% pusat penanganan kasus anak terinfeksi HIV. ${ }^{11}$ Di RS Cipto Mangunkusumo, semua subyek pengguna obat ARV lini kedua menggunakan sediaan atau formulasi dewasa berupa tablet. Hal tersebut merupakan salah satu tantangan dalam penanganan kasus anak terinfeksi HIV di Indonesia.

Kelemahan penelitian kami beberapa hal tidak tercatat dengan baik di dalam rekam medis dan tidak dicari secara aktif karena merupakan penelitian observasional. Data-data seperti kepatuhan minum berobat, efek samping, dan kesulitan minum obat dengan sediaan tablet tidak terdokumentasikan dengan baik.

Sebagai kesimpulan, masalah gagal terapi dan resistensi obat ARV harus diwaspadai pada penanganan jangka panjang anak terinfeksi HIV. Subyek yang menggunakan obat ARV lini kedua pada penelitian dini tidak terlalu banyak diakibatkan karena deteksi kegagalan terapi masih lebih banyak berdasarkan kegagalan klinis dan imunologis. Perlu dikembangkan lebih lanjut perangkat diagnostik sederhana yang dapat memprediksi kegagalan virologi lebih dini untuk daerah dengan sumber daya terbatas.

\section{Daftar pustaka}

1. Departemen Kesehatan Republik Indonesia Direktorat Jenderal Pengendalian Penyakit dan Penyehatan Lingkungan. Laporan situasi perkembangan HIV/AIDS di Indonesia sampai dengan Maret 2012. Diunduh dari: http://www.aidsindonesia.or.id/laporan-kementerian-kesehatantriwulan-kesatu-tahun-2012.html, Diakses pada tanggal 11 Mei 2012.

2. Ditjen PPM \& PL Depkes RI. Statistik Kasus HIV/AIDS di Indonesia sampai dengan Desember 2008. Jakarta; Departemen Kesehatan RI: 2009

3. Joint United Nations Programme on HIV/AIDS (UNAIDS).UNAIDS data tables 2011. UNAIDS; 2011

4. Puthanakit T, Oberdorfer A, Akarathum N, Kanjanavanit S, Wannarit P, Sirisanthana T, dll. Efficacy of highly active antiretroviral therapy in HIVinfected children participating in Thailand's National Access to Antiretroviral Program. Clin Infect Dis 2005;41:100-7.

5. Clavel F, Hance AJ. HIV drug resistance. N Engl J Med 2004;350:1023-35.

6. Departemen Kesehatan Republik Indonesia Direktorat Jenderal Pengendalian Penyakit dan Penyehatan Lingkungan. Pedoman tata laksana infeksi HIV dan terapi antiretroviral pada anak di Indonesia. Jakarta; Departemen Kesehatan RI: 2008.

7. World Health Organization. Antiretroviral therapy for HIV infection in infants and children: towards universal access. Recommendations for a public health approach, 2010 revision. Austria; WHO: 2010.

8. Panel on Antiretroviral Therapy and Medical Management of HIV-Infected Children. Guidelines for the Use of Antiretroviral Agents in Pediatric HIV Infection. 
August 16, 2010. h. 1-219. Diunduh dari: http:/laidsinfo. nih.gov/ContentFiles/PediatricGuidelines.pdf. Diakses pada tanggal 15 Oktober 2010.

9. Emmett SD, Cunningham CK, Mmbaga BT, Kinabo GD, Schimana W, Swai ME, dkk. Predicting virologic failure among HIV-1-infected children receiving antiretroviral therapy in Tanzania: a cross-sectional study. J Acquir Immune Defic Syndr 2010; 54:368-75.

10. Bunupuradah T, Puthanakit T, Kosalaraksa P, Kerr S, Boonrak P, Prasitsuebsai W, dkk. Immunologic and virologic failure after first-line NNRTI-based antiretroviral therapy in Thai HIV-infected children. AIDS Res Ther 2011; 8:40.

11. TREAT Asia Pediatric HIV Observational Database (TApHOD), The International Epidemiologic Databases to Evaluate AIDS (IeDEA) Southern Africa Paediatric Group. A biregional survey and review of first-line treatment failure and second-line paediatric antiretroviral access and use in Asia and southern Africa. J Int AIDS Soc 2011;14:7.

12. Ruel TD, Kamya MR, Li P, Pasutti W, Charlebois ED, Liegler T, dkk. Early virological failure and the development of antiretroviral drug resistance mutations in HIV-infectd Ugandan children. J Acquir Immune Defic Syndr 2011;56:44-50.

13. Davies MA, Moultrie H, Eley B, Rabie H, van Cutsem G, Giddy J, dkk. Virologic failure and second-line antiretroviral therapy in children in South Africa - The IeDEA Southern Africa Collaboration. J Acquir Immune Defic Syndr 2011;56: 270-8.

14. Buck WC, Kabue MM, Kazembe PN, Kline MW. Discontinuation of standard first-line antiretroviral therapy in a cohort of 1434 Malawian children. J Int AIDS Soc 2010;13:31.

15. Sauvageot D, Schaefer M, Olson D, Pujades-Rodriguez M, O'Brien DP. Antiretroviral therapy outcomes in resource-limited settings for HIV-infected children $<5$ Years of Age. Pediatrics 2010;125:e1039.

16. Colebunders R, Moses KR, Laurence J, Shihab HM, Semitala F, Lutwarna F, dkk. A new model to monitor the virological efficacy of antiretroviral treatment in resource-poor countries. Lancet Infect Dis 2006;6:539.

17. Larru B, de Mendoza C, Bellon JM, de Jose MA, Mellado MJ, Soriano V, dkk. Predictive factors of virological success to salvage regimens containing protease inhibitors in HIV-1 infected children. BMJ Infect Dis 2007;7:55.

18. Van Rossum AM, Geelen SPM, Hartwig NG, Wolfs TFW, Weemaes CMR, Scherpbier HJ, dkk. Results of 2 years of treatment with protease-inhibitor-containing antiretroviral therapy in Dutch children with Human Immunodeficiency Virus Type 1. Clin Infect Dis 2002; 34:1008-16. 